\title{
The Productivity of Vocational Schools: The Role of Efficiency, Fairness, Transparency, and Accountability of Financial Management
}

\author{
Agoestina Mappadang ${ }^{1, *}$ Khusaini $^{2}$ \\ ${ }^{1}$ Department of Accounting, Economy, Universitas Budi Luhur \\ Jl. Ciledug raya, RT 10/RW 2, Petukangan Utara, Kec. Pesangrahan \\ Kota Jakarta Selatan, DKI Jakarta 12260, Indonesia \\ E-mail corresponding : agustina.mappadang@budiluhur.ac.id \\ ${ }^{2}$ Master of Accounting, Budi Luhur University, Jakarta
}

Received 18 December 2020, Revised 8 March 2021, Accepted 15 March 2021

\begin{abstract}
In the last decade, vocational education quality is one of the productivity measurements. To measure productivity were internal and external efficiency, the quality of graduates, financial management, and effectivity. This study aims to examine and analyzed the effect of the principles of efficiency, fairness, transparency, and accountability in financial management on vocational school productivity simultaneously or partially. The sampling technique used was a census. Data collection methods using questionnaires. Data analysis methods using logistic regression analysis. The results of this study could be concluded that teachers' perceptions of school productivity were good, but they're still needs to be an improvement in school policies in keeping schools productive and even increasing. The results both partially and simultaneous were the application of the principle of transparency and accountability proven to contribute significantly to increasing school productivity. Whereas the principle of efficiency and fairness didn't significantly contribute to increasing the productivity of vocational schools in Business and Management in Tangerang Municipality. While simultaneously, the application of the principles of efficiency, fairness, transparency, and accountability in school financial management contributed to creating school productivity. The implication of this research was useful for improving the quality and productivity of vocational schools in Tangerang Municipality.
\end{abstract}

Keywords: efficiency; fairness; productivity; accountability; transparency

\section{INTRODUCTION}

Productivity can be interpreted as the relationship between input and tangible results in the form of goods and services (Tangen, 2002). Productivity can also be expressed as an input needed to produce output, to produce some of the output/output per unit (Atkinson, 2013; Hanushek \& Ettema, 2017). In education, school productivity is the ability of school administrators to elaborate school inputs to produce efficient and effective school output, like private sector (Hanushek \& Ettema, 2017), also planning, arrangement, and utilizing the resources (Sobandi, Yuniarsih, Rasto, \& Adman, 2020). Productive schools can be reflected in the form and nature of school organizations because schools are able to provide opportunities in the form of increasing the quantity and quality of competencies possessed by students and graduates.

School productivity is a measure of the quality of education delivery, relevance, and efficiency, as well as graduates. Thomas (2013a) argues that to measure productivity is effectiveness, internal efficiency, external efficiency, and graduate quality. These problems can be solved by managing input into tangible results or called productivity. In-Law Number 20 the Year 2003 Article 15 it is stated that "vocational education is secondary education which prepares students primarily to work in certain fields" (Pemerintah-DPR, 2003). Vocational education in Indonesia is represented by vocational high schools (SMK) and vocational aliyah madrasas (MAK). In contrast to general high school (SMA), SMK is a secondary school level that provides education services and students are given applied sciences so that their graduates can adapt and can directly work in industries or other agencies by their fields of expertise.

The vocational graduation rate in Banten in 2017 is $99.10 \%$ and in 2018 the graduation rate is $99.80 \%$. In current conditions, SMK graduates still 
face problems in labor absorption. This condition can be seen from data published by the Central Statistics Agency for vocational graduates in Indonesia who were not yet absorbed in the workforce in February 2018 at $8.92 \%$ and in August 2018 it increased to $11.25 \%$. This figure is higher compared to high school graduates who have not been absorbed in the workforce, namely $7.95 \%$ in August 2018. While in Banten Province, the number of SMK graduates who have not been absorbed is quite high, which is $11.65 \%$. This condition reflects the external efficiency of the vocational school level in Banten Province. While the number of vocational school dropout rates in Tangerang Municipality in 2018 reached 484 students and the number of students who repeated as many as 142 students. The number of teachers who already have certification is $40.3 \%$ and those who have not been certified are 59,7\% (Kemendikbud, 2018). Meanwhile, the amount of the education budget provided through the Banten APBD for education is $15.33 \%$. The budget from the State Budget for Vocational Schools in Banten is Rp. 42.92 billion.

To measure the performance of vocational schools and the quality of education services can use the accreditation ranking achieved by vocational education units. The better the accreditation ranking, the better the quality and performance of the school or vice versa. The state of SMK accreditation in Tangerang Municipality in 2018 showed that the number of SMK that were accredited A was $24.4 \%$, accredited B was $34.5 \%$, accredited $C$ was $11.6 \%$, and the rest was not accredited. This illustrates that vocational schools in Tangerang still need to improve the quality of schools and their performance.

Based on the empirical data above illustrates that the productivity of vocational schools in Banten, especially in the city of Tangerang shows that the indicators have not been optimally reviewed. This is caused by several factors, namely transparency, accountability, and efficiency (Prapliyati \& Margunani, 2019), accreditation (Asopwan, 2018), school leadership, teacher competence, and work environment. This is what underlies the authors to conduct school productivity research related to education funding. The correlation between the two has been examined by previous researchers who concluded that education funding has significantly increased, but school productivity has decreased. But on the contrary, Thomas (2013b) proves that education funding has contributed $62.2 \%$ to the improvement of vocational productivity. These results make it clear that education funding from both the government and the community has a significant role in driving increased school productivity.

Educational services provided must uphold the principle of justice. Because the principle of justice will be able to provide broad and equitable access to educational services to all school-age children. Providing access to educational services for all people regardless of race, ethnicity, religion, gender, or socioeconomic status. This has been arranged by the government so that education practitioners can guide it (Pemerintah Republik Indonesia, 2008a). So the fairer the education service is provided, the school productivity will increase, even education will be more evenly distributed.

Efficiency in managing education funds is done by optimizing access, quality, relevance, and competitiveness of education services (Pemerintah Republik Indonesia, 2008b). Efficiency in the world of education has a relationship with the utilization of limited educational resources to achieve high optimization. In education funding, efficiency will be determined by the accuracy of the utilization of the education budget by giving priority to educational input factors that can refer to student achievement.

Government Regulation No. 48/2008 states that "the principle of transparency in the management of education funds is carried out by fulfilling the principles of propriety and good governance by the government, regional governments, communities, and education units (Pemerintah Republik Indonesia, 2008b). Transparency can be interpreted that everyone is free to access information about the administration of government. Information about policies, the process of making and implementing them, and the results achieved are entitled to be known transparently by the people. Likewise, related to school financial transparency is also entitled to be accessed by school stakeholders, including teachers, students, school committees, NGOs. With the existence of transparency in the management of school finances, the community will no longer hesitate to donate their finances to fund their children's schools.

With the transparency of school budget management, it is intended to increase school productivity, because schools are not likely to corrupt financial management. Bearing in mind that each stakeholder can jointly supervise the school budget. To avoid misuse of the education (school) budget, transparency of the management of education finance is needed. However, there was a reverse research result that concluded that there was no proven significant transparency of school financial management to increase school productivity (Prapliyati \& Margunani, 2019; Raeni \& Setiyani, 2014).

One of the considerations in making decisions by stakeholders related to the form of evaluating economic performance, especially the public sector, is the existence of public accountability. Education is one form of public schools and semi-public or private schools. Therefore, school financial management must apply good accountability. In the management of school finances, the accountability of activities carried out by the school to stakeholders and the general public by the school. The principle of applying accountability in managing school finances must be 
implemented properly so that schools are able to use funds from the public and the government effectively and efficiently.

The results of previous studies prove that the application of good accountability can increase the productivity of vocational schools. Also, the application of the principle of accountability has been regulated by the government through Government Regulation No. 48/2008 stating that "the principle of public accountability in the management of education funds is carried out by providing accountability for activities carried out by organizers or education units to educational stakeholders by laws and regulations" (Pemerintah Republik Indonesia, 2008a). The principle of school financial accountability by the way schools are accountable for programs implemented as one of the public sectors to school stakeholders so that they can be used as material or input for decision making.

Based on the brief description above, the writing of this paper is intended to examine the effect of the principles of efficiency, fairness, transparency, and accountability in financial management on the productivity of vocational schools either partially or simultaneously. The analytical tool used is the logit regression model. The results of the study are expected to provide an overview of the financial management of each school and its influence partially and simultaneously on the productivity of vocational schools in the City of Tangerang.

The Indonesian government's efforts to improve the quality of human resources through policies to increase the number of vocational education, namely secondary and tertiary education. Vocational education applies learning that is more technical than theoretical. Therefore, the results of vocational education are resources that have technical skills and innovation. Industrial innovation requires human resources who have technical and trade skills (Jones, 2018). It revealed that political and technical policies are factors that influence educational productivity. In addition, other factors in the form of organization and financing also contribute to increasing school productivity. The link between financing and productivity is supported by previous research which states that education spending does not significantly affect school productivity in the USA. While private schools spend $60 \%$ more than public schools, the output is the same.

Productivity research can be studied from various economic, social, cultural, and individual perspectives, institutions as a supplement to knowledge. Despite their limitations, studies that have analyzed educational productivity usually choose to use test scores as a measure of their main output. Related to school financial management this research uses the Stewardship theory cited which states that the responsibility for financial management and reporting in schools lies with schools as financial managers.
While facilities and funds are provided and provided by stakeholders.

The results of this study are also supported those who conducted a study that there was a significant increase in education funding in the middle of 1960 to 2000 , but productivity declined. The results of the study are inversely proportional to other studies at the time. The results of this study are in line with research that stated that education funding has a significant positive effect (Thomas, 2013a). Related to the principle of efficiency, the study results show that there is a positive and significant correlation with productivity in Kendal Regency (Prapliyati \& Margunani, 2019), universities in Greece (Kyratzi, Tsamadias, \& Giokas, 2015).

Efficient in the management of education budget is the benefit of the budget that suits and takes into account the needs of each school. This means the use of education funds following the needs of students or schools (Sukardi \& Djalil, 2019). The previous study found that fairness has a positive and significant effect on improving school productivity (Raeni \& Setiyani, 2014). Moreover, Fair payment of money to employees will improve its performance (Hee, Ong, Ping, Kowang, \& Fei, 2019), so that school productivity will increase.

The principle of fair school financial management is the right to the ease and availability of access to information for school stakeholders. Iibi (2019) stated that respecting individual differences benefits the workplace by creating a safe and fair work environment where everyone has equal access to challenges and responsibilities in achieving work objectives. The results of the previous study showed that fairness correlated with school productivity (Raeni \& Setiyani, 2014).

This is following the principles of school financial management which are part of the indicators of good public governance contained in Government Regulation No. 48 of 2008 which stated that "the principles in the management of education funds by the government, regional governments, organizers, and education units established by the public consist of the principle of justice (fairness), the principle of efficiency, the principle of transparency, the principle of public accountability" (Pemerintah Republik Indonesia, 2008b). Based on the description above, the following hypothesis is defined:

H1 : There is a significant effect of the efficiency in financial management on the productivity of vocational schools

$\mathrm{H} 2$ : There is a significant effect of fairness in financial management on the productivity of vocational school

The principle of transparency in managing school budgets is an important factor in creating productive schools both in process, output, and outcome. Because, the parties who are entitled and in the interests of pieces of information transparency are donor agencies (private and government) and also 
parents (Utama \& Setyani, 2014). The results of previous studies showed that school budget accountability affected the productivity of schools (Prapliyati \& Margunani, 2019; Sukardi \& Djalil, 2019). Funding is not enough with transparency and honesty, but the fulfillment of financing standards is also important to increase productivity (Asopwan, 2018). However, (Raeni \& Setiya, 2014) found that transparency was not significant to increase the productivity of schools. The hypothesis can be defined as follow:

H3 : There is a significant effect of transparency in financial management on the productivity of vocational schools.

While the principle of accountability is an obligation to encourage better school financial management and public trust. The application of the principle of budget accountability is able to encourage school productivity. The results showed that there was a significant correlation to school productivity (Prapliyati \& Margunani, 2019; Raeni \& Setiyani, 2014; Setyawan, 2015; Sukardi \& Djalil, 2019), and regional apparatus units (Setiyawan \& Safri, 2016). This principle is in line with the National Education System Law No. 20 of 2003 concerning the Education System which states that the government, regional government, and the community are responsible for education funding. Therefore, the government and the community have a vital role in optimizing the available educational resources. From this, the following hypotheses are defined:

H4 : There is a significant effect of accountability in financial management on the productivity of vocational schools.

H5 : Simultaneously, there is a significant effect of the efficiency, justice, transparency, and accountability in the financial management on the productivity of vocational school.

\section{METHODS}

Quantitative research is the approach used in this study. While the research design is correlational because, in this study, the researcher will test the effect of the independent variable with the dependent variable. Researchers determine the population of Tangerang Municipality Vocational School teachers in the areas of Business and Management expertise. The target population in this study was productive teachers in the Accounting and Finance skills program of 186 teachers. The designated sampling technique was a census. The researchers distributed the questionnaires to all the samples, but the return questionnaire was 130 . However, the questionnaire was complete and worthy to be analyzed as many as 124 , so the researchers processed data of 124 samples.

Researchers determined the dependent variable of SMK (Y) productivity measured by 4 indicators, namely internal efficiency, external efficiency, and quality of graduates. Furthermore, the score obtained is given the symbol " 1 " if the productivity score is above average, and the score below average is given a score of "0". So the dependent variable is also called the latent variable or dummy. While the independent variables used are efficiency (X1), the principle of fairness (X2), transparency (X3), and accountability (X4). Indicators of efficiency variables are 3 , namely directed and controlled programs/activities, reduction in overlapping organizational functions, and simple, economical, and as needed. The principle of justice variable is measured by 4 indicators, namely basic fulfillment policy, poor student facilities, proportion of student recipients, and school dropout rate or school participation of rates (APS) if APS $<1 \%$ ).

The transparency variable is measured by 4 indicators, namely transparency of budget, transparency of document of budget, transparency of accountability report, and the available access to information. While the accountability variable is measured by 5 indicators, namely the involvement of stakeholders in the determination of APBS or budget of income and school expenditure, SOP conformity with implementation, the existence of output and outcome measures, periodic financial reports, and the implementation of annual LPJ. The data used are primary data, that is, researchers use a questionnaire in data collection. Before the researcher distributed the questionnaire, the researcher had tested the validity and reliability and stated that the questionnaire used was valid and reliable. The measurement scale on the questionnaire uses a Likert Scale with a value of 1 which means "Strongly Disagree" to 5 which means "Strongly Agree". The analytical method used in this study is Logit regression.

\section{RESULTS AND DISCUSSION}

The results of teacher perceptions of research variables productivity, efficiency, principles of fairness, and budget transparency indicate that teachers' perceptions of productivity of Vocational Business and Management in Tangerang Municipality of 124 respondents (male teachers amounted to a high category (achieving $80 \%$ score) or productive. If productivity data is made categorized as productivity with an average score above $35.86=1$ and belowaverage $=0$, then the perception that productive Vocational schools are 70 respondents or $56.5 \%$, while the teacher's perception of efficiency variables, principles justice, transparency, and accountability score $81 \%, 79 \%, 75 \%$, and $70 \%$ respectively. This can be stated that the Vocational School in Tangerang Municipality is effective, fair enough, transparent enough, and sufficient accountable in the financial management of school budgets. In logistic regression analysis for primary data, assumptions of normality, heteroscedasticity, and autocorrelation are no longer needed. However, the assumption of the multicollinearity in this model is still carried out to determine the linear relationship between independent 
variables. The results of the multicollinearity test with Pearson correlation produce correlation coefficient values smaller than 0.80 so it can be concluded that the model does not have multicollinearity problems. Furthermore, researchers conducted a model feasibility test by presenting an Iteration History, Omnibus Test, Hosmer and Lemeshow test, and Model Summary.

The Hosmer and Lemeshow test is used to ensure that the logit model applies to the dependent variable (goodness of fit). Then, the test is used to find out whether the empirical data used matches the research model (there is no real difference between the data and the model). The results of the Hosmer and Lemeshow test can be seen in the following table:

Table 1. Hosmer and Lemeshow Test

\begin{tabular}{cccc}
\hline Step & Chi-square & Df & Sig \\
\hline 1 & 8.765 & 8 & 0.363 \\
\hline
\end{tabular}

Source: SPSS 22 Processing Results (2020)

Based on table 1, the results of the Hosmer and Lemeshow test resulted in a calculated Chi-Square value of 8.765 and a degree of freedom of 8 , and a significance value (P-value) of 0.363 . Next, determine the Chi-Square table value with a significance level of $5 \%$ and $\mathrm{df}=8$, then a value of 15.507 is obtained. So the calculated Chi-Square value $=8.765<$ Chi-Square table $=15.507$ and the P-value Sig. $=0.363>0.05$ which means the model can be accepted and the researcher can continue testing the hypothesis.

The researcher also presents estimation results using logistic regression models to answer research questions and test hypotheses. Logit regression estimation results can be seen in Table 2 below:

Table 2. Estimation Results of Logit Regression Models with Dependent Variables: Vocational Productivity

\begin{tabular}{lcc}
\hline \multicolumn{1}{c}{ Variable } & $\begin{array}{c}\text { Coefficient } \\
\text { /Std. Error }\end{array}$ & Exp (B) \\
\hline Efficiency (X1) & 0.258 & 1.294 \\
& $(0.160)$ & \\
Fairness (X2) & -0.006 & 0.994 \\
& $(0.148)$ & \\
Transparency (X3) & $0.324 * * *$ & 1.328 \\
& $(0.106)$ & \\
Accountability & $0.297 * * *$ & 1.346 \\
(X4) & $(0.109)$ & \\
\hline \multicolumn{2}{c}{ Constant } & $-22.220 * * *$ \\
\hline Observation & 124 & 0.000 \\
-2 likelihoods & 119.576 & \\
Cox \& Snell R Square & 0.330 & \\
Nagelkerke R Square & 0.443 & \\
Sig. Hosmer- Lemeshow & 0.363 & \\
Test & & \\
\hline
\end{tabular}

Source: SPSS 22 Data Processing Results (2020)

Note: ${ }^{*} \mathrm{p}<0.1,{ }^{* *} \mathrm{p}<0.05, * * * \mathrm{p}<0.01$
The interpretation of the results of the estimation of this model is different from the multiple regression model because the resulting value is a probability. Based on table 2 above, mathematically the Logit regression equation can be written as follows:

Logit $\left(\frac{\pi}{1-\pi}\right)=-22,220+0,0,258 X 1-0,006 X 2+$ $0,324 X 3+0,297 X 4$

From table 1 and equation 1, it can be described or interpreted related to the coefficient value and the Odd Ratio or Exp (B) value. Logit regression model estimation results show that the efficiency variable has a P-value, Wald test value $(\mathrm{Sig})=0.106>0.05$, meaning that the efficiency variable (X1) has no significance on the productivity of vocational schools in Tangerang so that it can be declared that hypothesis 1 is not accepted. While the principle of justice variable (X2) has a P-value of Wald test $(\mathrm{Sig})=0.967>0.05$, meaning that the principle of justice variable (X2) has a partial effect that is not significant to the productivity of vocational, so hypothesis 2 is rejected.

The transparency (X3) and accountability (X4) variables have the P-value Wald test (Sig) respectively 0.002 and $0.006<0.05$, meaning that each variable of transparency and accountability partially has a significant effect on the productivity of vocational school schools in the City Tangerang, so hypothesis 3 and hypothesis 4 are accepted. While the simultaneous test uses the difference between -2 LogLikelihood of 49.702 and a significance value of $0.000<0.05$, then Ho is rejected. This result can be stated that at least there are 2 variables (transparency $=\mathrm{X} 3$ and accountability $=\mathrm{X} 2$ ) simultaneously affecting the productivity of vocational schools, so hypothesis 5 is accepted.

Based on table 2 above, the estimated results of the Logit regression model show that the Nagelkerke R Square value of 0.443 is greater than the Cox \& Snell Square value of 0.330 . This result can be stated that the ability of the efficiency variable (X1), the principle of fairness (X2), transparency (X3), and accountability (X4) explains the variance of SMK productivity by $44.3 \%$, and the remaining $53.70 \%$ is determined by other variables.

To find out how much the contribution of the influence of each independent variable on SMK productivity, the Logit regression model uses Odd Ratio or Exp (B) values (see table 2). The contribution of efficiency to increasing vocational school productivity is 1.294 times with the assumption of ceteris paribus. However, it is statistically insignificant, meaning that changes in efficiency have no impact on changes in vocational school productivity. Likewise, for the principle of justice variable which produces a negative coefficient of 0.006 and an Exp (B) value of 0.994 means an 
increase in the principle of justice by "1" will reduce school productivity by 0.994 -fold and is statistically insignificant with the assumption of ceteris paribus.

Meanwhile, the more transparent the budget management, there is a tendency to increase vocational school productivity. For every increase of transparency of "1", the tendency for a significant increase in productivity is 1,382-fold with the assumption of ceteris paribus. While the accountability variable also contributes significantly to the improvement of vocational school productivity. If the accountability of school financial management increases "1", then the tendency to increase productivity is 1,346 -fold with the ceteris paribus assumption.

\section{Effect of the Efficiency in Financial Management on the Productivity of Vocational School}

The results of hypothesis testing indicate that the variable of financial management efficiency of Vocational Schools in Tangerang Municipality has not been proven to contribute significantly in increasing school productivity. Although respondents perceive that the efficiency of school financial management is up to $80 \%$, it has not been proven to affect the productivity of vocational schools in Tangerang Municipality. This is due to the gap in teacher perceptions of the indicators that have been set, namely directed and controlled programs/activities, reduction in overlapping organizational functions, as well as simple, economical, and as needed. The results of this study are not following the mandate of Government Regulation Number 48 of 2008 concerning Education Funding which states that "education funding can be achieved if it optimizes access, quality, relevance, and competitiveness of education services" (Pemerintah Republik Indonesia, 2008a).

This study also does not support previous research which states that the more efficient the management of school finances, the school productivity will increase (Prapliyati \& Margunani, 2019). They argue that budget efficiency is necessary because it plays an important role in the achievements of school programs. The principle of efficiency does not mean the use of minimal budgets, but the allocation and distribution of budgets for each activity using existing budgets. Besides that, efficiency is not always related to the school budget/finance but also relates to the school production process, changes in traditional learning patterns become more modern by utilizing existing technology, more productive ways of working, and utilizing school resources to achieve effective goals. In fact, the application of the principle of justice in the management of school budgets is also associated with binding the salary or income of teachers. Because the salary received by the teacher will contribute significantly to student performance. If student performance increases, school productivity will also increase.
The principle of efficient school financial management can be applied in a way that the school must be able to optimize the relevance of the school to the world of work, the quality of learning and management, and the competitiveness of school services. The accuracy and accuracy of the utilization of school budget or financial resources for educational inputs is a requirement in financial management, to achieve student achievement.

\section{Effect of the Fairness in Financial Management on the Productivity of Vocational School}

Fairness is related to the acquisition of the right for all citizens to take advantage of the system of freedom by the provisions of the legislation in force. In schools, fairness must be guaranteed by the school leadership of the rights of all school members and the community to the freedom of the system prevailing in schools. In this case the right to financial gain, proper education services, the right to school information, and the right to express opinions for school progress. Fairness is the basis of financial management. Budget allocation and distribution managed by schools are carried out fairly and sustainably. Because fairness affects the increase in school productivity. However, in this study, the results of hypothesis testing do not prove that there is a significant relationship between fairness and increasing the productivity of vocational schools in the city of Tangerang. This result is not by research that stated that school financial management efficiency significantly contributed to increasing school productivity (Raeni \& Setiyani, 2014).

This insignificant research is because teachers' perceptions of the principle of justice are still lacking, schools still do not apply justice in financial management. School residents, especially teachers, have not thought that the school has not implemented a policy of fulfilling basic rights for students, teachers, governance staff, and the community. For students the fulfillment of basic rights in the form of good learning services, the guidance of homeroom teachers and counseling teachers, as well as freedom of opinion at school. In addition, facilities for underprivileged students are still limited, schools have not allocated an education assistance budget for students who excel, and dropout rates exceed the threshold of $1 \%$. This condition is one of the reasons schools are increasingly less productive. Therefore, it is hoped that schools will uphold the principle of justice because they can contribute to better schools, greater community support for schools, schools capable of competitiveness, produce graduates who are ready to work, and achieve both academic and non-academic will increase.

Effect of the Transparency in Financial Management on the Productivity of Vocational School

The principle of transparency in managing school finances means that the school has 
implemented and guaranteed openness from internal and external parties of the school regarding the management of school finance. According to respondents' perceptions, the school is not yet transparent to all teachers and students as well as the general public, but the new school is transparent to the school committee of the school. Openness in managing school finances will have an impact on improving school good governance. With the transparency or openness of school budgets, all stakeholders can participate in budget oversight to avoid deviations from the school budget. If the school can guarantee budget transparency, it will have an impact on improving the quality of schools so that school productivity can increase. This concept is consistent with this study which can prove the research hypothesis that transparency has a significant effect in increasing school productivity. The higher the level of budget openness, the possibility of school productivity has increased by 1.382 times.

The results of this study are consistent with previous research which states that school financial transparency has a significant effect on school productivity (Prapliyati \& Margunani, 2019; Setyawan, 2015; Sukardi \& Djalil, 2019). On the other hand, the results of this study are not supported by another research which concluded that school budget transparency did not have a significant effect on school productivity (Raeni \& Setiyani, 2014). The researcher argues that access to information provided by schools related to school financial management is difficult to obtain, even though with current information technology advancements, schools can utilize school websites to provide information related to periodic budget management. Furthermore, that each secondary school had available administrative staff who manage finances, but the books used to record revenues and expenditures were not informed to the school community, so it seemed that public accountability had not been carried out optimally.

\section{Effect of the Accountability in Financial Management on the Productivity of Vocational School}

School productivity is also influenced by the application of the principle of accountability in school financial management. The results of this study prove a significant relationship between accountability and school productivity. The results of this study also confirm the Stewardship theory. In this theory, it is stated that the financial management in a school is guided by the principle of managing education funds and is accountable to stakeholders. The results of this study are also in line with the theory of good governance, which states that to realize schools with good governance, school leaders must implement the principles of good governance, one of which is accountability. The application of good governance theory will also have an impact on improving school quality. The results of this study are consistent with previous studies which concluded that the principle of accountability in school financial management has a significant effect on school productivity (Hanson \& Olson, 2018; Prapliyati \& Margunani, 2019; Setyawan, 2015; Sukardi \& Djalil, 2019). In addition, schools should apply the principle of accountability, because it will facilitate schools in meeting school accreditation standards. The fulfillment of school accreditation standards, specifically financial management standards contributed to creating productive and competitive schools (Asopwan, 2018).

Accountability in school financial management has a significant effect on school productivity because schools perform financial accountability well, thereby increasing public confidence in school financial managers. Accountability of financial management at the Vocational School of Tangerang is implemented at the time of the compilation and stipulation of the School Revenue and Expenditure Budget, the implementation of school activities following the established SOPs, and annual responsibility report (LPJ) periodically. Even vocational high schools with the status of the state have been provided by the provincial government in the submission of the budget and LPJ online. Submission of budget activities and school activities through Simral software (https://bantenprov.go.id/link/simral) to be determined a school program and its budget. While private schools have not carried out good budget accountability, because it depends on the policies of each foundation that manages the education unit. Therefore, schools should strive to realize the openness and accountability of financial information to stakeholders, especially teaching staff as internal stakeholders. This effort can encourage the creation of a teacher's work climate so that the quality of teachers will improving. Improving the quality and performance of teachers certainly helps schools in creating productive and competitive schools.

\section{CONCLUSION}

The results of this study can be concluded that teachers' perceptions of school productivity are good, but they're still needs to be an improvement in school policies in keeping schools productive and even increasing. The results of testing the research hypothesis both partially and simultaneously are the application of the principles of transparency and accountability proven to contribute significantly to increasing school productivity. Whereas the principle of efficiency and fairness does not significantly contribute to increasing the productivity of vocational schools in Tangerang Municipality. While simultaneously, the application of the principles of efficiency, fairness, transparency, and accountability in school financial management contributes to creating a productive school.

Furthermore, based on the conclusions of the results of this study, researchers recommend to 
schools and policymakers as follows; 1) schools should increase community involvement in the decision-making process optimally so that transparency and accountability of schools can be maintained well. It aims to increase public confidence in schools; 2) For Banten Provincial Government, it should encourage private schools to create a school budget / financial management system that upholds the principles of justice, transparency, and accountability. As for state schools, the government can provide rewards and punishments for schools that apply these principles;

The limitation in this study is that the results of the study rely heavily on the perception of teachers' accounting skills programs, business and management fields, and do not include the perception of principals and students. Therefore, future researchers can include principals and students as samples to strengthen the generalization of the research results. Another drawback of this study is ignoring personality variables in improving the productivity of vocational schools. Future researchers can include varied personalities (Sari, Sujanto, \& Matin, 2020) as one of the determining factors. The last limitation of the research is that the form of relationship between variables is direct. Future researchers can use a direct and indirect relationship model. They should use moderating or intervening variables in the form of a principal's leadership model to increase school productivity. The model or analysis tool used is path analysis or structural equation modeling.

\section{ACKNOWLEDGEMENT}

The author would like to thank the editor and any reviewers for their supportive comments and suggestions for this research.

\section{REFERENCES}

Asopwan, D. (2018). Studi Tentang Akreditasi Dalam Meningkatkan Produktivitas Sekolah. Indonesian Journal of Education Management and Administration Review, 2(2).

Atkinson, R. D. (2013). Competitiveness, Innovation and Productivity: Clearing up the Confusion. The Information Technology \& Innovation Foundation, (August), 1-7.

Hanson, T. A., \& Olson, P. M. (2018). Financial literacy and family communication patterns. Journal of Behavioral and Experimental Finance, 19, 64-71. https://doi.org/10.1016/j.jbef.2018.05.001

Hanushek, E. A., \& Ettema, E. (2017). Defining Productivity in Education: Issues and Illustrations. The American Economist, 62(2), 165-183. https://doi.org/10.1177/0569434516688207

Hee, O. C., Ong, S. H., Ping, L. L., Kowang, T. O., \& Fei, G. C. (2019). Factors Influencing Job Satisfaction in the Higher Learning Institutions in Malaysia. International Journal of Academic Research in Business and Social Sciences, 9(2), 10-20. https://doi.org/10.6007/ijarbss/v9-i2/5510

Iibi, J. (2019). Managing Employee Diversity for Effective
Productivity in Secondary School in Rivers State, Nigeria. KIU Journal of Social Sciences, 5(2), 201$213 . \quad$ Retrieved from http://www.ijhumas.com/ojs/index.php/kiujoss/articl e/view/527/488

Jones, A. (2018). Vocational education for the twenty-first century, (August), 1-11. Retrieved from https://melbourne-

cshe.unimelb.edu.au/_data/assets/pdf_file/0011/28 45775/Final-Anne-Jones-paper1.pdf

Kemendikbud. (2018). Neraca Pendidikan Daerah Provinsi Banten 2018. Jakarta, Indonesia: Kemdikbud.

Kyratzi, P., Tsamadias, C., \& Giokas, D. (2015). Measuring the efficiency and productivity change of Greek universities over the time period 2005-2009. International Journal of Education Economics and Development, $\quad 6(2), \quad 111-129$. https://doi.org/10.1504/IJEED.2015.070620

Pemerintah-DPR. (2003). Undang-Undang Nomor 20 Tahun 2003 tentang Sistem Pendidikan Nasional. Jakarta, Indonesia: Lemabaran Negara RI Nomor 4301. https://doi.org/10.16309/j.cnki.issn.10071776.2003.03.004

Pemerintah Republik Indonesia. (2008a). Peraturan Pemerintah Nomor 47 Tahun 2008 tentang Wajib Belajar. Lembaran Negara Indonesia 4863.

Pemerintah Republik Indonesia. (2008b). Peraturan Pemerintah Republik Indonesia Nomor 48 Tahun 2008 tentang Pendanaan Pendidikan. Kemenristekdikti. Retrieved from https://kelembagaan.ristekdikti.go.id/wpcontent/uploads/2016/08/PP48-2008DanaDik.pdf

Prapliyati, \& Margunani. (2019). Pengaruh Akuntabilitas, Transparansi, dan Efisiensi Pengelolaan Keuangan Sekolah Terhadap Produktivitas Sekolah. Economic Education Analysis Journal, 8(3), 1030-1044. https://doi.org/10.15294/eeaj.v13i3.35725

Raeni, \& Setiyani, R. (2014). Pengaruh Prinsip Keadilan, Efisiensi, Transparansi, dan Akuntabilitas Pengelolaan Keuangan terhadap Produkstivitas SMK. Economic Education Analysis Journal, 3(1). https://doi.org/10.1017/CBO9781107415324.004

Sari, P. G., Sujanto, B., \& Matin, M. (2020). The Effect of Personality and Quality of Work Life (QWL) on the Work Productivity of Middle School Teachers. EDUTEC: Journal of Education And Technology, 4(1), 1-14. https://doi.org/10.29062/edu.v4i1.76

Setiyawan, H., \& Safri, M. (2016). Analisis Pengaruh Akuntabilitas Publik, Transparansi Publik Dan Pengawasan Terhadap Kinerja Satuan Kerja Perangkat Daerah Di Kabupaten Bungo. Jurnal Perspektif Pembiayaan Dan Pembangunan Daerah, 4(1), 51-72.

Setyawan, M. H. D. (2015). Pengaruh Prinsip Keadilan, Transparansi, dan Akuntabilitas Pengelolaan Anggaran terhadap Produktivitas Sekolah (Persepsi Guru SMP N 3 Mertoyudan Magelang). Universitas Negeri Semarang. Retrieved from https://lib.unnes.ac.id/20689/1/7101410051-s.pdf

Sobandi, A., Yuniarsih, T., Rasto, \& Adman. (2020). Learning Facilities: Can It improve the vocational school productivity? Journal of Educational and Social Research, 10(4), 146-155. https://doi.org/10.36941/jesr-2020-0074

Sukardi, M. S., \& Djalil, M. A. (2019). Effect of Effectiveness, Transparency and Accountability of Budget Management on High School Productivity in 
the Regency of Bener Meriah, Province of Aceh, Indonesia. East African Scholars Journal of Economics, Business and Management, 2(12), 790797.

https://doi.org/10.36349/easjebm.2019.v02i12.015

Tangen, S. (2002). Understanding the concept of perineology. In Proceedings of the 4th Asia Pacific Industrial Engineering and Management Systems Conference (APIEMS2002), Taipei (pp. 275-277). Beijing: Asia Pacific Industrial Engineering \& Management Society (APIEMS).

Thomas, P. (2013a). Faktor Determinan Produktivitas
Sekolah. Jurnal Penelitian Dan Evaluasi Pendidikan, 17(1), 55-71. https://doi.org/10.21831/pep.v17i1.1361

Thomas, P. (2013b). Penerapan Model Produkstivitas SMKN Bisnis-Manajemen di Kota Semarang. Pendidikan, Jurnal Dinamika, Ekonomi, VIII(1), 110.

Utama, A. D., \& Setyani, R. (2014). Pengaruh Transparansi, Akuntabilitas, Dan Responsibilitas Pengelolaan Keuangan Sekolah Terhadap Kinerja Guru. Dinamika Pendidikan, 9(2), 100-114. https://doi.org/10.15294/dp.v9i2.4886 